\title{
Decision-Making Process to Be a Legislative Candidate for the First Time
}

\author{
$1^{\text {st }}$ Very Julianto* \\ Department of Psychology \\ State Islamic University Sunan Kalijaga \\ Yogyakarta, Indonesia \\ very.psi07@gmail.com
}

\author{
$2^{\text {nd }}$ Muhammad Rapiq Hilal \\ Department of Psychology \\ State Islamic University Sunan Kalijaga \\ Yogyakarta, Indonesia \\ rafiqhilal338@gmail.com
}

\begin{abstract}
This study aims to analyze the decision-making by legislative candidates for the first time. The method chosen is qualitative with a case study approach. The subjects in this study were 4 men and 1 woman. The results of this study indicate that at the stage of problem assessment there is one theme, namely informants who decide to become legislative candidates because they are offered by parties and the public or are nominated. In addition, the five informants were in a stress-free atmosphere when the KPU stated that the informants did not meet the requirements to become members of the legislature. That is because the initial process for becoming a legislative candidate is not based on personal desires but rather because it is offered an offer by the party and the community or is nominated. Despite the many problems after choosing to become a legislative candidate for the first time, the informants were committed to holding out until the election ended with some consideration. However, the informant still decided to become a legislative candidate for the first time as a final decision
\end{abstract}

Keywords—candidate, decision-making, election, legislative

\section{INTRODUCTION}

Indonesia is a country that upholds democratic values which are defined as a form of government of the people, by the people and for the people. The sentence means that what is in the people is part of the people and for the welfare of the people going forward, because basically the power of the people, for the benefit of the people, is through the people. As a democratic country, Indonesia provides great opportunities for all its people to actively participate in political activities, especially those who become cadres of certain political parties. Therefore, besides making the election as an effort to determine the head of government, Indonesia also made the election as an effort to elect people's representatives or commonly known as candidates.

People's representatives consisting of DPR RI, DPD, Provincial DPRD, and Regency/ City DPRD. has three functions, namely the legislative function, the budget function, and the supervisory function which are carried out as a representation of the people. The legislative function is carried out by legislators as holders of power to form laws. The function of the budget means that the legislative member discusses and gives approval to the national budget $(\mathrm{APBN})$ at the national level to the government, as well as at the provincial and district/city levels. While the oversight function is carried out through the implementation of laws and the implementation of the approved APBN [1].

The decision to become a legislative candidate is often chosen by individuals with various factors to consider. Being a legislative candidate is a big decision in someone's life because it not only involves the individual concerned but also involves the family and the future. A legislative candidate is someone who will later act to represent his party in the legislature directly elected by the people through general elections. The legislative body has the task of formulating a public policy that binds all people in the form of a law, and generally represents the people through political parties and is elected through general elections [2].

Based on the regulations of Law No. 10 Years 2008 regarding the Election of Members of the DPR, DPD, and DPRD several requirements must be met by someone to be able to submit themselves as a legislative candidate or commonly abbreviated as a legislative candidate, that is, they are 21 (twenty one) years of age or older, devoted to God Almighty, residing in the unitary territory of the Republic of Indonesia, capable of speaking, reading and writing in Indonesian, having the lowest education level of high school or equivalent, loyal to Pancasila, the 1945 Constitution, and ideals of the proclamation of August 14, 1945, were never sentenced to imprisonment, threatened with imprisonment, threatened imprisonment of 5 years or more, physically and mentally healthy, registered as a voter, willing to work full time, become a member of a political party participating in the election, be nominated in only one representative institution, and be nominated in only one constituency, and be able to read the Qur'an (specifically NAD local legislative candidates) [3].

Being a legislative candidate certainly must prepare and consider all the consequences that will be faced, in terms of time, mentality, and even political costs. From how to overcome the lack of capital for political costs, to benefit from each step he does. In some ways, they have principles like entrepreneurs, how to think profit and profit. Even if they fail to become members of the legislature at the first opportunity, they have enough social capital to advance at another time. In contrast to mentally not good. In his mind, politics is an investment whose output is in the form of profit and loss, often in size with the amount of rupiah, if not profit in that period then he experiences stress that results in mental disorders [4]. 
Becoming a legislative candidate is a big decision, the decision to become a candidate usually involves processes that are not simple, to mental or material readiness. The decision-making process to become a legislative candidate for the first time is starting from assessing information/ problems, surveying/looking for alternatives, and considering alternatives to be a unified process with internal and external factors so that individuals arrive at the point of taking commitment to decide to become a legislative candidate to the first time [5].

The individual decides to become a legislative candidate, through a series of decision-making processes to be able to determine the best decisions in his life. Decision making is taken by everyone with an intentional element and is not done haphazardly and the problem is known in advance and formulated, and the solution must be based on the selection of the best alternative from the available alternatives [6]. Janis \& Mann mentions five stages to reach a stable decision that is, involves the process of thinking and considering everything that will affect the individual and its environment. Starting from the process of assessing problems, looking for alternatives, considering various alternatives and expressing commitment and feeling the consequences of decisions taken [7].

Individuals who make decisions in a very conscious condition by knowing the impacts that are considered carefully. Decisions taken are the result of thinking by following the era, culture, goals, beliefs, and ability to think rationally [8]. Kendal \& Montgomery mentioned that several factors influence each individual in making decisions, namely internal factors including preference, emotion, belief and external include action and circumstance [9]. After going through several stages of the decisionmaking process, deciding to become a legislative candidate for the first time as a final decision, and being influenced by internal and external factors, individuals who decide to become a legislative candidate for the first time will surely gain post-scalding experience, both positive experiences and experienced negative experiences.

\section{MATERIALS AND METHODS}

This type of research used by researchers is a type of descriptive qualitative research with the approach taken in this study is a case study. Yin defines case studies as a more suitable strategy if the main question of a study regarding how and why, if the research has little opportunity to control the events to be investigated, and if the focus of research lies in contemporary phenomena (present) in the context of real life.

The informants in this study were chosen based on certain considerations, where the considerations were based on the following criteria: (1) legislative candidates; and (2) first time registering as legislative candidates. Informants in this study were 5 legislative candidates domiciled in Yogyakarta. The first subject initials BU is a woman aged 24 years, the second subject Af is 24 years old, the third subject is MR 34 years old, the fourth subject is FD 30 years old, and the fifth subject $\mathrm{PH}$ is 24 years old. The data retrieval process was also carried out by using the results of recommendations and information from the informants who were blown (significant other) in the field. The number of closest informants is not limited in this study, but in the field who are willing to be the closest informant, there are 3 subjects. The following are the characteristics of the closest informant (significant other) in this study: 1) Individuals who are daily close to informants, such as brother, sister, child, friend, neighbors, and friends; and 2) knowing a lot about the life of the informant.

In this study data collection was conducted using targeted general interview techniques and semi-structured interviews. The conduct of interviews and the ordering of questions are adjusted to the circumstances of the informants in the context of the actual interview. The tool used in this research interview is by using a voice recorder that functions to record interviews to make it easier for researchers to compile interview transcripts and make it easier to analyze data. Besides other assistive devices are pens, block notes, statements of the willingness of informants and interview guidelines.

Research data were analyzed with analysis techniques developed by Moloeng. Furthermore, it is said that the analysis phase consists of data organization, data reduction, coding, categorization, and interpretation stages. Data organization is the process of analyzing data starting with organizing data by analyzing all available data from various sources. Data reduction ie the researcher focuses on looking at data related to the research theme and tries to rule out findings in the research process that are not related to the research theme.

Coding is a process of coding the data obtained from the field based on verbatim or interview transcripts that have been made by researchers. Furthermore, the categorization of the researcher chooses each part that has been coded, which has similarities so that these similarities can form one big theme that can be translated into discussion or conclusions. Then the final analysis stage is interpretation, during the research process, the researcher seeks to understand the research data in greater depth. The researcher has a perspective on what is being studied and interprets the data through this perspective

\section{RESULTS}

The decision-making process to become a legislative candidate at the five informants can be seen from several stages of the process.

\section{A. Information Access}

When an individual receives unclear information or information that he thinks is far from expectations, he will maintain an attitude about the action he wants to take. Receiving this unclear information causes individuals to experience temporary conflict (personal temporary crisis) and begin to doubt what has been believed so far. Individuals will start looking for alternatives if the key questions give a positive response after the first decision.

In the first informant, BU, BU was offered to be a legislative candidate, and BU admitted that his nomination to be a legislative candidate was only limited to meeting the requirements of $30 \%$ of women legislative candidates. BU was offered directly by the chairman of the KNPI to become 
a legislative candidate, even though BU himself felt that BU did not yet fully understand the world of politics.

"Continue to be told by those who invited me, said he was okay to join this only to the extent of what is the requirement of 30 percent of women. Well, I've come with me to electoral area 5. My sequential number is long", (BU/ W1: L: 37-40).

The same thing was experienced by AF informants, after being approved to be proposed as a legislative candidate to represent the millennial generation, $\mathrm{AF}$ then asked for related scenarios, information related to scenarios and also asked for advice for families and seniors in the party.

"There I will also continue to ask what will happen? He assured that the important thing was to learn first, join the long-standing legislative candidates because there were a number of them because the system was regeneration and we learned and yes, the chapter on money already said that capital was not difficult to think first that was important to move", (AF/ W1: L: 109-115).

\section{a. Look for Alternatives}

At this stage, individuals look for various alternative actions and ask for advice or information from others to deal with the problem, even if it violates or does not comply with their commitments. In the MR informant, for example, he asked his parents for advice, especially from his father, who was one of the religious leaders in the village with his description, because MR claimed he wanted to get qualified advice that could strengthen MR for deciding to become a legislative candidate for the first time. Likewise with other informants, who ask for advice and advice to those closest to them related to the shooting.

"Most of the people who talk like that, seeing the current conditions often see the condition of the legislature so the legislative members should be like this and this is an advice that must be taken, basically they have to be working in such a situation", (MR/ W2 : L: 221-226)

In line with MR informants, FD informants also asked parents and wives first to ask permission specifically, initially the wife did not allow her to become a candidate for fear of something bad happening to FD in the future. However, after being persuaded finally FD's wife also allowed and received support from the family, especially FD's wife.

"Yes family first, family is what I said earlier that the decision to do politics is not an easy thing because we will involve all segments of the family, my wife does not agree to participate in politics, but as time goes by understanding that needs it when entered the system because if we were just bragging outside, wanting to change policies but not entering the system was very difficult”, (FD/ W1: L: 156-166).

\section{b. Consider Alternatives}

At this stage, the five informants experienced the same thing, which received positive and negative responses related to the shooting. For example, in the FD informant, the positive response was that the FD felt confident that many people in the hamlet were supportive because they were considered to represent the sons of the region, where for almost decades there were no indigenous people in their hamlet who dared to become legislative candidates. There is a negative response that is the destruction of the campaign props including banners, billboards, flags, banners damaged by irresponsible elements. However, FD's attitude towards the negative response, FD reacted calmly and felt that it was all-natural, just who was the strongest to survive.

"Oh community, yes, in my village, thank God, $80 \%$ God willing, I will vote because I am considered the son of the region representing them and for only decades there were no young people or no indigenous people there who flared despite the controversy due to the bases Formerly the ABC party base was there with me from the party PS* (party initials), the party cadres automatically came out to support me, so that is where my enthusiasm arose. The people there support me so from what to install APK, Banner, etc. (FD/W1: L: 174-187). There is a negative response, it is natural, it's fair, many flags are missing, banners are a lot helped, I first installed the APK flag, my billboard included the beginning, others didn't install it, I already installed it, only 1 night last it all disappeared all over the district my flag is missing and someone ripped it. This is politics, we must be ready when the flag is torn off, we must be prepared to report to the Supervisory Committee even though this is not easy enough, let's just try to find out", (FD/ W1: L: 190-200).

Other informants namely AF, there are several choices in considering alternatives related to their shooting, AF acknowledged that his experience in politics is still minimal, for his campaign strategy, AF uses more social media than it has to socialize to the public.

"If it is rated, the ahh e 20 is because the reason I said is that the lack of experience is very good so this is a stepping stone for the next 5 years more based in the regions", (AF/ W1: L: 216 -221)

From the very beginning, the AF scan was confused because many psychological factors that were received by $\mathrm{AF}$ in response from the public, AF was afraid that the sound that appeared could not be predicted.

"In the beginning, I did have confusion, many demands, psychological factors were accepted or not in the community how many voices came up, afraid of being rushed towards me", (AF/ W2: L: 110-113). "I'm really sad a lot, bro, during the scanning process, because there are also many internal problems, the term is broken, so there are those who join the new direction movement. Yea, it's still sad there, so I didn't expect my friends who have been beside me at the turnaround", (AF/ W2: L: 125-131).

\section{c. Expressing Commitments}

After internally deciding to take new actions, individuals begin to discuss carefully the application of the decision and state their intentions to others. At this stage, the five informants were committed to continuing the shooting until it was finished. As experienced by $\mathrm{AF}$ and $\mathrm{PH}$ informants 
after the process of considering various alternatives and deciding to become candidates until the election is over. The AF informant initially felt that he wanted to withdraw from the nomination, but because he had already considered and considered other things, AF finally decided to go ahead in the nomination as a legislative candidate. AF hopes that with the face of young people who are actively participating in the political world, it is hoped that it can give a new color.

"Yes, I want to withdraw, hah, but it was already wet, right, back off again, but we can't", (AF/ W2: L: 4547). I am as a young man who doesn't look like he should be stretched, hopefully, there is a new color, yes, mas, because you said that your father is unique too", (AF/ W2: L: 50-23). "I am because of the millennial generation, so like in IG I make funny packaging that is not serious because I see that my party's design is serious. I don't even take the successful team directly from people who are not involved in political parties", (AF/ W2: L: 83-89).

Likewise, with $\mathrm{PH}$ informants who feel confident about their decision to become a legislative candidate, this decision has reached $80 \%$ even according to the $\mathrm{PH}$ itself when it was wet into politics, of course, it must be totality and $100 \%$ must be optimistic to get enough votes.

"Now it's 80 percent already", (PH/ W1: L: 149).

"Well, if you're sure about that, now you have to have 100 percent. That is only 80 percent preparation on D-day, it must be 100 percent, how do you prepare for it, from a long time ago, you have to prepare the strategy and mentality", (PH/ W1: L: 162-169).

\section{d. Managing Negative Feedback}

Many individuals feel happy and comfortable with new decisions taken without hesitation. But often the situation is disturbed by the emergence of negative feedback from other parties. The individual will persist at this stage until he is confronted with an event or thing that is very powerful to cause dissatisfaction with the choices that have been made. If that happens, he will go through the three stages above, then look for other alternatives that are different and better. The five informants experienced negative responses from their environment related to their scenarios, but the five informants were able to respond to it well and remain in the decision to become a candidate until the election is over.

In the BU informant, for example, after deciding to become a legislative candidate, BU was offered a variety of political money lures that were so lucrative, BU felt scared and confused. BU thinks that if he does not continue to become a legislative candidate, he cannot because he has already been registered with the KPU and resigning will also damage his reputation and party's reputation. However, BU remains in its commitment to remain a candidate for legislative members until the legislative elections take place.

"I was last in WA because I did not come to the meeting and I was right together with his father from the party, he said you need how many campaigns later I dare 10 to 20 million as long as you want a campaign, well from there I am afraid, he said this is not the name, not money politic. What is not money politic sir what is the money for. He said to ask for his account number, from there it was like a negotiator, I said I could not", (BU/ W2: L: 71-80). "I thought that if I wanted once I would continue to be worked on, I did not do not think about me is it really just a name, so what is it really like I have to go ahead and just stag here. That's what I'm confused and I'm sorry", (BU/ W2: L: 87-92).

\section{B. DISCUSSION}

The decision-making process is certainly through a series of processes that generally aim to get the results of the decision in accordance with what is expected. It is the same as deciding to become a legislative candidate through various processes, namely assessing information or problems, surveying alternatives, considering alternatives, stating commitments, and surviving negative feedback and consequences. When an individual receives unclear information or information that he thinks is far from expectations, he will maintain an attitude about the action he wants to take. Receiving this unclear information causes individuals to experience temporary conflict (personal temporary crisis) and begin to doubt what has been believed so far. Individuals will start looking for alternatives if the key questions give a positive response after the first decision. Affirmed by Janis and Mann (Hartati 2014), when an individual faces a challenge and ends successfully in the first stage, the condition can provide something new. Decision-makers will be better prepared to face new findings to take action as desired.

The process of assessing problems or information carried out by each individual can have a positive or negative influence on the decisions taken. The five informants had different problems in the initial process of deciding to become a legislative candidate. But there is one similar problem experienced by the five informants, this is considered to be the main problem and even becomes the root of the emergence of other problems, namely the five informants when the initial process of deciding to become a legislative candidate due to encouragement or offers from various parties from outside himself to become a legislative candidate.

For informants, offers and support and encouragement from outside are what make the start of the process of deciding to become a legislative candidate. Of the five informants, none of the informants took the initiative to register as candidates for the legislature on their own. All at the offer of the bearer party, encouragement from a group of people, close friends or colleagues and also members of a party. This is consistent with what was expressed by Kemdal \& Montgomery that there are factors that influence a person to make decisions, one of which is an external factor, namely circumstance. Factors from outside the individual, such as the influence of others and the environment that can influence when making decisions and in this condition, individuals tend to be passive [10].

The next process according to Janis \& Mann in making decisions is to survey alternatives or find alternatives to solve problems. This alternative search was carried out by the five informants by asking other people's opinions, such 
as family, relatives and close friends [11]. This is done by the five informants with consideration to get advice or information from others to deal with the problem. Most of the decisions lead to initial commitments, but with the strong stimulus it receives, it starts looking for new information about other better alternatives.

The next process after assessing information or problems and looking for alternatives is to consider alternatives. The individual at this stage goes into deeper analysis and evaluation by focusing on the positive and negative sides of each available alternative until he feels confident to choose an alternative that suits his purpose. In general, this stage is marked by doubts where the individual is no longer satisfied with the previous action or action but also has not yet committed to a new alternative. When he reaches the point of being sure that he knows where the best choices are, he will usually continue to be responsive to new information [12].

In the shooting process, the five informants considered what would happen after deciding to become a legislative candidate both in terms of positive and negative aspects as well as whether to stop and not continue the drawing because it was based on consideration. The consideration for continuing to be a legislative candidate is the encouragement of moral support from the family, all party members, and a group of citizens. Another consideration is that the KPU has already been listed, and is considered to be a representative of the native son in his hometown and is optimistic, and represents the millennial generation. However, another consideration from the five informants to not continue to be a candidate is the negative response from individual residents who damaged the campaign props. Do not have a large capital for shooting, do not have permanent income, feel inferior because they are not married. Then the existence of transactional politics, and the existence of broken friendships caused by running for candidates. However, the five informants remained in their main stance, namely continuing their candidacy to become a legislative candidate after considering some things.

Then the next decision making process according to Janis \& Mann is to state commitment and survive negative feedback. After internally deciding to take new actions, individuals begin to discuss carefully the application of the decision and state their intentions to others [13]. Many individuals feel happy and comfortable with new decisions taken without hesitation. But often the situation is disturbed by the emergence of negative feedback from other parties. The individual will persist at this stage until he is confronted with an event or thing that is very powerful to cause dissatisfaction with the choices that have been made. If that happens, he will go through the three stages above, then look for other alternatives that are different and better.

The five informants decided to remain committed to continuing the scanning, although there were many negative responses from the surrounding environment and also not a few positive responses received by each informant. Deciding to continue this decision was the final decision due to several reinforcing reasons including, because they had already registered at the KPU, there was family support and support from all party members and support from close friends. Then to maintain personal and party good name, and wish to add insight. Besides, they also became part of the representatives of the millennial generation and representatives of the native sons of each informant.

In addition to the five stages of the decision-making process mentioned by Janis \& Mann which include assessing information or problems, surveying alternatives, considering alternatives, stating commitments, and surviving negative feedback and consequences. Several factors that a person to decide to become a legislative candidate for the first time, namely internal and external factors [14]. As mentioned by Kemdal \& Montgomery the first internal factor is emotion. This factor is related to feelings, positive and negative reactions to changes in situations and conditions of individuals responding to certain events. Emotion is a potential and predictable driver of decision making [15].

In terms of emotions, the informants felt different emotions and on the other hand felt the same emotions when they decided to become the first legislative candidate. Positive emotions felt by the five informants were they felt happy and proud and grateful for being known by many people and given trust. On the other hand, some informants felt stressed, dilemma, confused, doubtful, sad and worried about the shooting. The other internal factor is preference. This factor is an individual desire or interest and hopes, dreams and goals that will be realized to get a concrete or tangible goal. The five informants had hopes that they would like to change the system for improvement in the legislative body, bring a new color to political education, make special applications to monitor the performance of legislative members, improve the bureaucracy, and want to embrace developing community potential.

The third internal factor in decision making according to Kemdal \& Montgomery is belief, that is, a belief in something can lead to certain behaviors and proof of what is believed to be a reference for each individual. Of the five informants, the whole is the same that a belief in family and friends or those closest to them that supports and encourages informants to become legislative candidates is a reinforcement for informants deciding to become legislative candidates [16].

In addition to internal factors that influence individuals to make decisions, other factors that influence decision making according to Kemdal \& Montgomery are external factors. This external factor consists of action and circumstance. Action is related to the active interaction of individuals in decision making with the environment, the aim is to find information, exchange ideas, and take commitments [17]. While circumstance is a factor from outside the individual, such as the influence of others and the environment that can influence when making decisions and in this condition, individuals tend to be passive.

From the five informants namely; BU, AF, MR, FD and $\mathrm{PH}$, none of the informants took the initiative to register themselves as legislative candidates on their own free will. All at the offer of the bearer party, encouragement from a group of people, close friends or colleagues and also the support of members at a party. Then regarding the postscenes experience of the five informants, it was found that 
some of the informants felt normal after the shooting, on the other hand, there were those who felt happy to be known by many people because of the shooting and tested whether or not mentally strong to deal with various kinds of things that were received both positively and negatively. It takes a lot of capital to shoot. There is a change in mindset and insight about politics. There are changes in attitudes and behaviors so that more people can meet often. Have new experience and for the next shoot, must have a mature campaign strategy.

As for the other findings obtained in this study namely, that the decision of the Commission stated that the five informants in this study no one had qualified to become a legislative member. But the five informants received it with relief, not to stress or experience undesirable things. This is because the initial process of becoming a legislative candidate is not based on personal desires, but is caused by being offered by the party and the community or being nominated.

\section{CONCLUSION}

The decision-making process of becoming a legislative candidate for the first time, through five stages, namely assessing the problem or information, looking for alternatives, considering alternatives, stating commitment, and surviving negative feedback. At the problem assessment stage, there is one main theme, namely the informants who decide to become a legislative candidate because they are nominated by their closest people, starting from their family, friends, community, and colleagues in the party.

Although there are some problems experienced by legislative candidates in scalings such as lack of capital for shooting, there is money politics, destruction of campaign props, lack of experience and knowledge of campaign strategies, only to meet the requirements of $30 \%$ of women legislative candidates, then pitting sheep among candidates which is different, scoffs at informants because they are not married and do not have permanent jobs and other conditions that are perceived as informant problems.

Factors that influence the decision-making process of becoming a legislative candidate for the first time are two factors, namely internal factors found during the five decision-making processes. External factors in the form of support and encouragement to the informants obtained from those closest to them namely family, parents, community members, party members who in this study also suggested the informants make the decision to remain a legislative candidate.
Researchers are fully aware that the research carried out still has many shortcomings, so researchers provide advice. The suggestions given by researchers are as follows:

1) For political psychologists or consultants, it is also important as a third person to be an advisor or provide input and consultation related to the shooting.

2) For the next researcher, the researcher suggests that if you are interested in examining similar themes or similar research subjects, you can explore research on the decision-making process of legislative candidates who have nominated several times but never passed, this will produce interesting new findings.

\section{ACKNOWLEDGMENT}

We thank our colleagues from State Islamic University Sunan Kalijaga who provided insight and expertise that greatly assisted the research, although they may not agree with all of the interpretations/ conclusions of this paper. We thank other party for assistance and comments that greatly improved the manuscript.

\section{REFERENCES}

[1] K Samah and R. S. Fransisca. "Mimpi Menjadi Caleg”. Jakarta: Kompas. 2014

[2] R. T. Saputra. "Sistem kaderisasi dan Penetapan Calon Anggota Legislatif dalam Pemilu 2009 (Studi Kasus Partai Golkar Kabupaten Penajam Paser Utara)”. Jurnal Ilmu Pemerintahan, Vol. 2 No. 01. 2014. pp 1829-1841.

[3] S. Hartati and Tuapattinaya, Y. I. F. "Pengambilan Keputusan Untuk Menikah Beda Etnis: Studi Fenomenologi pada Perempuan Jawa”. Jurnal Psikologi Undip, 13(1). 2014. pp. 34-41. https://doi.org/10.14710/jpu.13.1.34-41.

[4] W. Gunawan. Deteksi Kegagalan Dalam Pemrosesan Informasi Kognitif Dalam Pengambilan Keputusan Karir Remaja. Jurnal Noetic Psychology. Vol. 4 No. 2, 2014. pp. 127-145.

[5] S. Hartati and Tuapattinaya, Y. I. F, Op Cit.

[6] I. Syamsi. "Pengambilan Keputusan dan Sistem Informasi". Jakarta: Bumi Aksar. 1995

[7] S. Hartati and Tuapattinaya, Y. I. F, Op Cit.

[8] P. Atmosudirdjo. "Pengambilan Keputusan (Decision Making)". Jakarta: Ghalia Indonesia. 1982.

[9] R. Ranyard, W. R. Crozier, and Svenson. "Decision Making Cognitive Models and Explanatns". Accessed from https://epdf.tips/decision-making-cognitive-models andexplanations.html. 1997.

[10] R. Ranyard, W. R. Crozier, and Svenson, Ibid.

[11] S. Hartati and Tuapattinaya, Y. I. F, Op Cit

[12] S. Hartati and Tuapattinaya, Y. I. F, Ibid.

[13] S. Hartati and Tuapattinaya, Y. I. F, Ibid.

[14] S. Hartati and Tuapattinaya, Y. I. F, Ibid.

[15] R. Ranyard, W. R. Crozier, and Svenson, Op Cit.

[16] R. Ranyard, W. R. Crozier, and Svenson, Ibid.

[17] R. Ranyard, W. R. Crozier, and Svenson, Ibid. 